\title{
Bradoriid arthropods from the lower-middle Cambrian of Scania, Sweden
}

Maria Eugenia Dies Álvarez, Rodolfo Gozalo, Peter Cederström, and Per Ahlberg

Acta Palaeontologica Polonica 53 (4), 2008: 647-656 doi:http://dx.doi.org/10.4202/app.2008.0409

Three species of bradoriid arthropods from the lower to middle Cambrian transitional interval of Scania, southern Sweden, are described and illustrated: Beyrichona tinea from the top of the traditional lower Cambrian (Gislöv Formation; Ornamentaspis? linnarssoni Zone), and Hipponicharion eos and Alutella sp. from the basal portion of the traditional middle Cambrian (lowermost part of the Alum Shale Formation). The bradoriid fauna compares most closely with others previously described from western and eastern Avalonia (New Brunswick and England). The record of $B$. tinea suggests a correlation between the "Protolenus Zone" (Hupeolenus Zone) of western Avalonia and the O.? linnarssoni Zone of Scandinavia. Hipponicharion eos appears to be a fairly long-ranging species as it has previously been recorded from upper lower Cambrian or lower middle Cambrian strata in New Brunswick, Poland, and probably Sardinia. The record of H. eos from the lowermost part of the Alum Shale Formation suggests that this largely unfossiliferous interval in the Scanian succession is not younger than the Acadoparadoxides oelandicus Superzone. The genus Alutella has not previously been recorded from the Acado-Baltic Province.

Key words: Arthropoda, Bradoriida, taxonomy, biostratigraphy, Cambrian, Scania, Sweden.

María Eugenia Dies Álvarez [medies@unizar.es] and Per Ahlberg [per.Ahlberg@ geol.lu.se ], Geologiska institutionen, Geocentrum II, Lunds universitet, Sölvegatan 12, 223 62 Lund, Sweden; Rodolfo Gozalo [rodolfo.gozalo@uv.es], Departamento de Geología, Universitat de València, C/ Dr. Moliner 50, 46100 Burjassot, Spain; Peter Cederström [peter.cederstrom@eslov.se], Axelvoldsvägen 27, SE-241 35 Eslöv, Sweden;

This is an open-access article distributed under the terms of the Creative Commons Attribution License (for details please see creativecommons.org), which permits unrestricted use, distribution, and reproduction in any medium, provided the original author and source are credited. 
FoF Full text $(501.2 \mathrm{kB})$ 